\title{
SEZs and economic transformation: towards a developmental approach
}

\author{
Aradhna Aggarwal ${ }^{*}$
}

This study presents a three-pillared analytical framework for the success factors and development outcomes of special economic zones (SEZs). The core argument is that countries that adopt a well-structured approach towards SEZs that they can align with the broader development strategy, executive effectively, and continuously evaluate and manoeuvre over time, are more successful in achieving SEZ-led economic transformation than others. This requires strategic bureaucratic competencies to make the right choices and set clear strategic directions; strategic bureaucratic learning to dynamically and interactively engage in adjusting the strategies when needed; and strategic bureaucratic strengths to implement the strategy effectively. These elements in turn need an effective political leadership with a strong development focus that can energise and motivate bureaucracies. The study revisits the experience of successful, not-so-successful and least successful countries across the globe within this framework and concludes by raising some pertinent concerns about SEZ-led development strategy that emerge from the analysis.

Keywords: Special economic zones, economic transformation, conceptual framework, political will, bureaucratic capabilities, developmental state

JEL: E02 O1 O2 F1

\section{Introduction}

The proliferation of global value chains (GVCs) has revolutionised the world economy by opening new paths of industrial development for developing countries. Instead of building up industrial capacities from scratch, these countries can join existing supply chains and upgrade along them (Baldwin, 2013). This opportunity has unleashed intense competition among developing countries to attract GVC-linked investment using various policy tools. One policy tool that is increasingly believed to be most powerful in this drive is special economic zones (SEZs).

* Aradhna Aggarwal (Aradhna.aggarwal@gmail.com) is Professor in the Department of International Economics, Government and Business at Copenhagen Business School in Denmark. 
In recent years, SEZs have become the rage with policymakers around the world, who appear to be convinced of the usefulness of SEZs in bringing about industrial transformation and sustained growth, resulting in an unprecedented surge in their number. According to the World Investment Report, there are 5,400 zones in operation across 147 countries, (4,000 five years ago); more are being added, with more and more countries embracing them or updating or expanding the existing ones (UNCTAD, 2019). SEZs are physically delineated areas where host countries relax rules and regulations, build efficient infrastructure, and offer substantial fiscal and non-fiscal incentives in the hope of attracting GVC activities, which are highly responsive to business environments and costs. There is a general presumption that by facilitating the host country's insertion into GVCs, SEZs can drive trade, FDI inflows and technology transfers, which in turn generate spillover effects and catalyse the process of economic transformation in the wider economy. However, the evidence indicates that very few countries have managed to leverage SEZs to achieve far-reaching economic transformation (Aggarwal, 2012a). In several countries SEZs have succeeded in driving FDI, exports, production and employment, but they have had limited or little impact on the development process in the wider economy (FIAS, 2008; Frick et al., 2018). In many other countries, SEZs are utterly unsuccessful even in attracting investment and economic activity (Farole, 2011).

This result has raised a critical question: Why are the development outcomes of SEZs so varied? The burgeoning literature on critical success factors of SEZs focuses mainly on best practices to follow in developing SEZs to make them attractive for foreign investors. Indeed, there are concerns about the development spillovers of SEZs as well, but these are addressed by offering general policy prescriptions, such as lowering transaction barriers between SEZ and non-SEZ firms, and upgrading technical and human skills in the wider economy. What is missing in this literature is the vital link between SEZs and national development strategies. Instead, SEZs are viewed as a separate system within an economy, with little connection with the overall development strategy.

This article argues that the key to SEZ success lies in institutionalising the zones into policy and planning. More specifically, the SEZ policy needs to be an integral and sustainable part of the broader development strategy. Institutionalisation of SEZs does not mean entrenched SEZ practices; rather, it means that SEZs must be able to respond to the dynamic realities of the economy. Although a few studies (for instance, Zheng, 2016) have also argued for integrating SEZs into broader development strategies, there are few guidelines as to how to do that. This study addresses that gap in the literature and presents a cohesive, comprehensive and integrated three-pillared analytical framework for linking SEZs with broader development planning. I call this framework an "integrated institutional framework of SEZs" (IIF). The three pillars of the framework are, first, a well-structured strategic 
approach to SEZs, well grounded in a broader holistic economic development strategy; second, strategic dynamism in the approach towards SEZs, well informed by continuous changes in economic conditions to adapt the current SEZ strategies to new development challenges as well as opportunities; and third, effective implementation of these strategies.

The core argument is that successful countries are those that adopt a wellstructured strategic approach towards SEZs which they can effectively execute, and continuously evaluate and manoeuvre over time. This requires bureaucratic competencies to make the right choices and set clear strategic directions; strategic bureaucratic learning to dynamically and interactively engage in adjusting the strategies when needed; and strategic bureaucratic strengths along with strong political support to implement the strategy effectively. These elements in turn are contingent upon political will with a strong development focus and leadership that can energise and motivate bureaucracies to achieve the broader development goals to earn creditability, visibility and resources (Ellison, 1995). However, very few countries in the world can perform this feat. This explains why the stories of SEZ-led economic transformation are so few. The study revisits the experience of major SEZ users in the world to show that the performance of SEZs varies directly with these factors. It concludes by raising some pertinent concerns about SEZ-led development strategy that emerge from the analysis.

The rest of the article describes critical elements of each of the three pillars and revisits, within this framework, the experience of successful, not-so-successful and least successful countries across the globe. Success is defined by the extent to which SEZs could be leveraged for economic transformation in the wider economy.

\section{The integrated institutional framework of SEZs: three pillars}

\subsection{A well-defined strategic approach to align SEZs with national development strategy}

SEZs can be used to achieve a variety of economic and economic diplomacy goals. They can serve to promote trade and FDI, industrial growth and diversification, spatial rejuvenation and urbanisation, border development, regional integration or international relations. However, this does not happen automatically. It requires a well-articulated strategic approach. A strategic approach defines what policymakers expect to achieve with SEZs and how they plan to achieve that. According to the first pillar of the framework, it is critical that the strategic approach adopted for SEZs is aligned with the broader development strategy. An alignment between the zone programme and broader strategies of industrialisation helps ensure long- 
term political support and resource commitments to zone development. More importantly, the synergies between a strategic approach to SEZs and national development create a mutually reinforcing and self-supporting system wherein the benefits of zones flow forward, backward and vertically, expanding capacity and improving the competitiveness of the wider economy. But this calls for a high level of bureaucratic expertise to assess synergies and trade-offs among different policy options at different levels and set strategic direction for SEZs to develop mutually reinforcing policies for achieving national goals and objectives. Policymakers must have clear answers to three questions: why should SEZs be set up? How can they be aligned with the broader development strategy? What objectives should be assigned to SEZs and how they can be achieved?

Understanding the rationale of SEZs: It is noteworthy that SEZs are no panacea for all development ills of a country. The nature of investment-impeding challenges determines whether SEZs are warranted at all. SEZs are a tool to address essentially those investment-impeding, inefficient regulatory institutions that can change quickly but are not necessarily changed because of sociopolitical compulsions. If investment is impeded by structural conditions such as factor endowments, exchange rate valuation, inflation rates, lack of human skills, sociopolitical instability, or physical and geographical factors, SEZs will themselves be constrained by them. This means that the relevance of SEZs is context-specific and that policymakers should have a clear understanding of investment-impeding institutions and the usefulness of SEZs in targeting them.

Aligning SEZs with national development strategies: Three broad approaches to aligning the two may be identified: complementary, reinforcing or central:

- Complementary (or enclave) approach: In a tariff-distorted economy, the role of SEZs is essentially to counter the anti-export bias created by a protectionist development strategy. In such a regime, SEZs can promote exports and foreign exchange earnings, and accelerate the growth process by allowing duty-free imports of the machinery and technology necessary for growth sectors. In a different scenario, a country that follows highly restrictive policies for FDI to protect domestic industries from competition may set up SEZs to promote FDI inflows within SEZ localities to ensure technology transfers and other related benefits. Similarly, non-capitalist countries may set them up as testing labs for reforms in the wider economy. In all these cases, the role of SEZs is to complement the national development strategy by overcoming the trade- and FDI-related challenges posed by the latter. Thus, SEZs need to be developed as enclaves of liberal trade and FDI policy in strategic locations near seaports, airports and highways, offering streamlined administrative procedures, basic industrial infrastructure, cheap labour, investor-friendly customs procedures, and a multitude of fiscal and non-fiscal concessions. 
In addition, SEZs can complement the development strategy in many other situations. For instance, countries that take the route of capital-intensive or high-tech industrialisation may focus on employment generation in SEZs. Or, SEZs may complement the national strategy of promoting large businesses by focusing on small businesses in SEZs, or vice versa. Or, SEZs may be leveraged to counter unbalanced regional development in the wider economy. The SEZ design, facilities, infrastructure and incentive structures will vary depending upon the objectives assigned to SEZs.

- National strategy reinforcing approach: Instead of being complementary to the development strategy, SEZs can be instrumental in reinforcing it. In a globalised regime, for instance, SEZs may underpin export-oriented industrialisation by driving FDI, exports and technology inflows. A critical element of this approach is to offer a highly favourable business climate in SEZs and combine it with intense marketing to attract FDI. Policymakers may adopt an enclave approach towards SEZs, whereby they focus only on making SEZs attractive and do nothing else. Alternatively, they may develop an action plan to catalyse FDI spillovers in the wider economy by promoting linkages with the rest of the economy. This may be achieved by lowering transaction costs between SEZs and outside firms to incentivise them to engage in business transactions. A more proactive approach would be to design SEZs strategically to attract FDI in those industries that are targeted as priority industries in the broader development strategy. Entry into GVCs would promise access to a global pool of new technologies, skills, capital and markets, as well as learning opportunities through technology spillovers in the target industries. As the economy transitions from one stage of development to another and targets new industries, it faces new challenges - technology gaps, patchy supply chains and insufficient scale. governments can manoeuvre SEZs as policy laboratories to reduce learning costs and expose firms to global product standards. Thus, SEZs may serve as incubators of ideas and economic and industrial policies for catalysing growth and economic development in the wider economies. In addition, SEZs can also reinforce national strategies of promoting large businesses (as in India); or small businesses (as in Taiwan Province of China) or balanced regional development (Republic of Korea) or regional cooperation (the growth areas of Mali-Burkina Faso-Côte d'Ivoire or Brunei-Indonesia-Malaysia-the Philippines).

- Development-centred approach: The third alternative is to place SEZs at the centre of the development strategy (as in China). This approach is based on the notion that externalities created by SEZs can drive growth. One body of literature in this line of thinking proposes to align investment in the rest of the economy with that attracted by SEZs to build domestic 
capacities in SEZ industries. In this case, instead of picking winners and building domestic capabilities in them, policymakers can focus on developing domestic production capabilities in SEZ industries. To do so, they need to develop policies, agencies and institutions; and proactively fund networks of researchers, start-ups, established firms and consortia to ensure advancements in all segments of the production processes to build domestic capabilities along the value chains. As they build domestic capabilities, they can target more sophisticated market segments such as design, marketing and branding. This is referred to as "vertically-specialised (or smart) industrialisation" (Milberg et al., 2014).

Alternatively, SEZs can be the core of cluster-based industrialisation. Cluster development in emerging economies faces institutional bottlenecks caused by a lack of entrepreneurial dynamism and high spatial transaction costs. SEZs can overcome these constraints by lowering both transaction and production costs. A successful cluster strategy requires a number of conditions: a critical mass of capable and competitive local suppliers in components, machinery and services to support the cluster industries; a network of research and development (R\&D) and higher education institutions most integral to innovation and upgrading in business institutions; entrepreneurial skills; and continually improving pools of skills, technology, infrastructure and capital. The action plan based on the objective of cluster development focuses on creating these conditions in and around SEZs.

SEZs can thus support, reinforce or be at the centre of a variety of national strategies. To perform this task requires a high level of bureaucratic capability which itself is contingent on technical expertise, level of enthusiasm, political support and leadership to achieve the mission.

Setting SEZ objectives with a commensurate action plan: A set of objectives needs to be developed with a clear understanding of how each objective contributes to the overall strategic role proposed for the SEZs. But, the objectives and strategic goals remain philosophical statements with no grounding in reality if they are not accompanied by a well-designed action plan. An action plan describes the way the goals of SEZs are realised. Generally, it is observed that policymakers tend to provide a highly inflated vision of SEZs, illuminated with a comprehensive set of objectives, but no clear-cut action plan to achieve them. This mis-mapping between policy ambitions and action plans affects the development outcomes and public perceptions of SEZs. 


\subsection{Strategic dynamism}

SEZs must be able to respond to the dynamic realities of the economy. For this to happen, the strategic approach towards SEZs needs to be continuously informed by strategic learning. As development takes place, domestic conditions change, and new challenges and opportunities emerge in the economy. At the same time, new agents of change appear; there are shifts in power, interests, perceptions and positioning of the existing actors; and there is demand for new institutions to adapt to new realities. The changing institutional dynamics pose new demands, new goals and new institutional challenges. In line with these dynamics, policymakers must assign new roles, objectives and preferential policy packages to SEZs, and continuously upgrade the existing ones. Instituting monitoring and evaluation (M\&E) mechanisms within the SEZ policy can play a crucial role in this process. Monitoring involves regular collecting of information and tracking of the achievement of results; evaluation is the systematic and objective periodic assessment of the SEZ policy including its objectives, design, implementation, outcomes and impacts. M\&E provides government officials and stakeholders with the means to learn by doing. Different methods may be adopted for M\&E depending on the objectives, indicators identified for evaluation, and availability of both data and human resources. However, M\&E is worthwhile only to the extent that it is used to introduce dynamism in the SEZ policy. There can thus be two-way dynamic linkages between SEZs and the wider economy. SEZs catalyse the growth process by addressing inefficient institutions and upgrading the economy, which in turn requires SEZs to also be upgraded to push the economy up the development ladder. This initiates a circular process, which has self-reinforcing and cumulative effects on the economy.

\subsection{Strategic implementation}

Efficient execution of the strategic approach is crucial to the success of SEZs. It is linked positively with bureaucratic strengths, which in turn draw on the technical, managerial and social skill sets, as well as the commitment of bureaucrats and the political support provided to them.

First and foremost, it is noteworthy that SEZ policy is implemented through the collective efforts of various public and private organisations, which may have conflicting agendas, incentives and concerns (Matland, 1995). Although this is true of many other public policies, conflicts in some of those policies are still quite manageable. However, SEZs are incredibly controversial. Effective implementation of SEZs depends on horizontal coordination across government departments, vertical coordination between layers of government, and public support. In many countries (India, for instance), conflicts between interest groups have been at the centre of the failure of the SEZ policy. There is evidence in the literature that SEZs 
are successfully implemented in countries where the top authority regulates SEZs directly (e.g., Bangladesh, Morocco, the United Arab Emirates, and Jordan) or where the state has assumed a strong development role (e.g., China, the Republic of Korea and Taiwan Province of China).

Second, SEZs' success is critically linked to their ability to attract investment, particularly FDI, in the first place. This ability depends on onsite, offsite, social and technological infrastructure, as well as regulatory facilitation, facilities, services provided to SEZ tenants and marketing efforts, each of which has financial implications. SEZs require massive financial resources for their development, management, operations and promotion. Even when SEZs are developed by the private sector, there are huge public costs for offsite development and administration.

Third, private participation in SEZ development does not reduce the public sector responsibilities. It requires administrative capabilities within host governments to ensure adequate regulation, facilitation and implementation without friction between the public and private sectors (FIAS, 2008).

Fourth, for the successful implementation of SEZs, macro management of the economy is essential to create an environment in which trade and investment can grow exponentially. Such management requires a set of support policies directed at trade and investment, including membership in multilateral trade agreements and regional trade agreements, bilateral agreements on FDI, and multilateral investment guarantee agencies; regulation of monetary, fiscal, and exchange rate policies; physical property rights as well intellectual property rights; and efficient legal systems.

Finally, it requires well-designed strategies for risk and cost management. The two types of risks attached to SEZs are market risks and SEZ-related risks. Market risks arise from business cycles, political upheavals, and macro mismanagement, whereas SEZ-specific risks involve money laundering and fraud, non-compliance, and changes in the government attitude towards SEZs. In addition, the literature is replete with the economic, social and environmental costs of implementing SEZs. Bureaucratic strengths play a crucial role in handling these challenges. Overall, the implementation of SEZ projects is not about creating mere infrastructure; instead, it is rather complex and calls for a well-designed implementation strategy that needs to be instituted within the policy design, along with the objectives and action plan.

The three-pillared framework presented earlier provides a comprehensive set of conditions for leveraging SEZs for economic transformation. At the core of this framework is the argument that it is particularly important that the government adopt a highly structured approach to developing, implementing and reviewing SEZ policies and strategies. To achieve phenomenal development outcomes using SEZs, the three pillars must continuously reinforce each other. 


\section{The integrated institutional framework and the global experience}

In this section, I revisit the SEZ experience of major SEZ-user countries across the globe within the framework discussed above to provide new insights on their performance. In the absence of SEZ data, I use the available evidence to identify three groups of countries: most successful, not-so-successful, and least successful or unsuccessful, where the term "success" is used to represent the extent to which countries have been successful in leveraging their SEZs to bring about economic transformation in the wider economy.

\subsection{Most successful countries}

By far, China, the Republic of Korea and Taiwan Province of China have been and remain the most successful economies in leveraging SEZs to achieve far-reaching economic transformation. All of them have experienced a high level of sustained economic growth over a number of years unparalleled in economic history. SEZs remain a key element of their fully structured development strategies. Given their unique national, social and institutional contexts and national development strategies, they have followed different policy approaches to SEZs, which they continuously manoeuvre and effectively implement to achieve phenomenal success in transforming their economies.

The strategic approach: In the 1960s, the Republic of Korea embarked on an import-substituting industrial strategy in the wider economy with a focus on importsubstituting heavy industries (fertilizers, cements, steel, machinery and oil refining). To counter the anti-export bias of the regime, it created SEZs of the enclave variety (officially called "manufacturing-oriented free trade zones") to attract FDI in export-oriented light industries that would bring much-needed foreign exchange for its import substitution programme, promote exports, absorb the vast educated workforce and provide access to new technologies to promote competitiveness in light manufacturing without posing any competition to domestic companies. It was clearly the complementary approach towards SEZs.

In contrast, Taiwan Province of China adopted the "development strategy reinforcing approach" to SEZs (officially termed as export processing zones, or EPZs). It placed a major focus on small and medium enterprises in the light consumer sector as part of its development strategy and leveraged EPZs to upgrade them technologically at an early stage of their development. The government adopted both reactive and proactive policy approaches to encourage linkages between EPZ firms and nonEPZ firms. As part of its reactive policy, it lowered transaction barriers between the two to encourage subcontracting and local sourcing. According to Wang (1990), 
in 1988, a thousand Taiwanese firms were subcontracted by EPZ firms, to the tune of US\$392 million. Using a proactive approach, the government supported small businesses in the wider economy to help them build their productive capacities to participate in these transactions through the use of targeted credit, subsidies, and incentives packages as well as import protection (Amsden, 1989; Evans, 1995; Wade, 1990). Integration with GVCs strengthened the technological competitiveness of small and medium enterprises by giving them access to a global pool of new technologies, skills, capital and markets. Once integrated with GVCs, these enterprises moved from the assembly of imported inputs to increased local production and sourcing as original equipment manufacturers (OEMs), then to original design manufacturing (ODMs); and finally to the sale of their own branded merchandise (as OBMs).

China, the third country in our analysis, traversed a distinctly different trajectory. It adopted an "SEZ-centred development approach" and placed SEZs at the centre of its cluster-based industrialisation strategy. It laid the foundation for a distinct model of SEZs with large, city-like size and openness, and an institutional structure that provided considerable economic incentives and leeway to local authorities; these provided ideal conditions for cluster development. The proximity of China to Hong Kong (China) and its strategic location, together with extremely low wages, disciplined labour, reforms in land policy and massive investment into offsite infrastructure, turned China's SEZs into engines of remarkable growth (Zeng, 2016).

Dynamism: As these countries developed, they maneuvered their SEZs as well. In the Republic of Korea, where large conglomerates were at the centre of the growth process, SEZs had been marginalised by the late 1980s. In the aftermath of the East Asian crisis, when the country initiated the process of restructuring the economy and targeted the development of the logistics industry to position itself as a logistics hub in the region, it leveraged SEZs to reinforce this strategy. It upgraded its manufacturing zones with logistics facilities (Aggarwal, 2012b) and set up new logistics-oriented free trade zones. Between 2008 and 2010, both types of SEZs generated US $\$ 8.3$ billion of imports and US $\$ 14.6$ billion of exports, and employed 13,676 people (WTO, 2012). In 2002, however, the strategy of economic restructuring and balanced regional development placed SEZs at the centre, and the country transitioned from the enclave variety FTZs to large open SEZs, and initiated the "free economic zones" (FEZs) programme as part of its efforts to attract foreign investment, particularly in services and in ultra-high tech and R\&D. FEZs are world-class cities equipped with cutting-edge infrastructure and services, and they are at the centre of the ambitious goals of the development strategy. The official website of FEZs ${ }^{1}$ indicates the presence of 4,467 companies with FDI of

http://fez.go.kr/global/en/index.do. Accessed on 13 August 2019. 
US\$16 billion as of 2014. By broadening the base of the economy, these zones appear to have contributed significantly to the resilience of the Korean economy to crises (SaKong and Koh, 2010).

Like the Republic of Korea, Taiwan Province of China also maneuvered its SEZ strategy over time. However, while the former continuously upgraded the role assigned to SEZs in its development process, the latter has continued to follow the strategy of reinforcing the development strategy through SEZs. Taiwan's industrial structure underwent several transformations during the process of development (Wade, 2003; Smith, 1997); along with that process it upgraded its EPZs as incubators of new industries. In the late 1970s, to align with economic restructuring in the rest of the economy, EPZs were upgraded to attract capital-intensive activities; in the late 1980s, to high-tech industries; and in the late 1990s, to the logistics industry. The availability of domestic capabilities made it possible for zone enterprises to establish linkages with domestic producers and further augment their capabilities. This helped in developing a two-way relationship between EPZ and non-EPZ firms. EPZ investors have become important customers for Taiwanese companies outside the zones. In 2015, domestic inputs shipped into the Kaohsiung zone equaled 48 per cent of the zones' total export value (Crook, 2016). Despite the fact that the administrative regime has been simplified in the wider economy, EPZs still enjoy immunity from institutional rigidities in the labour market and the FDI regime. Currently, Taiwan Province of China has 10 EPZs and six logistics-oriented free trade zones. These zones are clustered together to form two growth poles, in Kaohsiung and in Taichung, which are reinforced by science parks and industrial parks of various types to act as the force driving their dynamism.

Encouraged by the initial success of SEZs, China launched a massive drive to create a myriad of smaller zones near existing zones, industrially developed locations, and existing clusters to generate synergies between them and promote a critical amount of economic activity. Numerous industrial clusters were created to complement the growth of SEZs. Synergies were created between the SEZs and regional economies by using appropriate policy packages and tax incentives to reap the benefits of increasing returns, external economies and complementarities. Agglomeration economies generated in the process turned the zones into industrial hubs of unprecedented magnitude. According to one estimate, by 2007, in 300 of 326 municipalities, there were 1,346 zones (Wang, 2013). The SEZ sector was also expanded vertically, by locating smaller SEZs within the larger ones to augment them further so that the benefits could also flow within the SEZs. In addition, the government played a catalytic role by promoting a network of R\&D facilities and higher education institutions and creating conditions for private entrepreneurship to thrive. Clustering of industries facilitated further entrants and investment by both foreign and domestic investors (Wang, 2013). 
China thus succeeded in transforming its SEZs into growth poles. The 11 city clusters formed by SEZs and industrial clusters, each of unprecedented size, collectively accounted for one-third of the population and two-thirds of economic output in 2015 (Bertaud, 2016). According to the official statistics, the Yangtze economic area alone accounted for 46 per cent of total exports in 2014 (GOC, 2015). Over time, increasing economic disparities at the regional level within China have led the government to develop strategies with a strong spatial focus. The government made SEZs the centrepiece of balanced regional development strategies. Since 2010, China has set up 135 additional economic and technological development zones across the country, with 77 of them located in inner areas. These were paired with successful SEZs in the East to provide a wide range of support in their development under the dyadic support network programme. Furthermore, in the 1990s, China initiated the development of border areas by setting up economic zones in these areas, in cooperation with Myanmar, Viet Nam and the Lao People's Democratic Republic. Recent years have witnessed the synthesis of China's development strategy with growing economic diplomacy. SEZs are being used as a critical tool of the new strategy. In the mid-2000s, the government adopted a policy of "going out" to encourage Chinese companies to promote the establishment of overseas industrial and trade zones. According to the Ministry of Commerce, ${ }^{2}$ in late 2017 Chinese enterprises had built 75 economic cooperation zones in 24 countries, with 3,412 enterprises operating in them and creating 209,000 jobs in the local regions. The number is likely to increase with more SEZs emerging along the Belt and Road Initiative of China. China has become a role model for the world in leveraging SEZs to drive growth.

Implementation: Implementing an evolutionary strategic approach could be a challenge. But, by maintaining a strong state in charge of development, these developing economies could exercise their powers for effective implementation of their development strategies and planning. Strong political backing has ensured efficient coordination between ministries and layers of government with little resistance from the public. On the economic front, all three economies offered investors a highly lucrative and comprehensive package of streamlined administrative control, generous tax incentives, preferential fees for land or facility use, reduced duties on imports, free or low-rent standard factories, flexibility in hiring and firing workers, depreciation allowances, good infrastructure, low wage rates and cheap land in order to generate a critical mass of activity within SEZs. Huge amounts of money was pumped into infrastructure, not only within SEZs but outside them, as well. In China, SEZ administrations were given the powers of provincial government, facilitating approval procedures, reducing administrative fees and enhancing the service function of government organs. They can develop

2 http://english.mofcom.gov.cn/article/newsrelease/press/201711/20171102669163.shtml. 
their own regulations to apply in their jurisdiction. All three countries adopted sound macroeconomic policies, investing in human capital and the quality of institutions. They instituted various export-promotion policies, such as undervaluation of their foreign exchange rates, elimination of quantitative restrictions and tariffs, and regional cooperation agreements. Political and social stability also contributed to the success of their SEZs.

The experiences of these countries indicate that a well-structured development model is a prerequisite to achieve phenomenal industrial transformation using the SEZ strategy. Setting up SEZs does not mean a reduced role for the government. Rather, it means an extended development role for it, strong bureaucratic competencies and political will, with a focus on the competitiveness of the economy and continuous strengthening of its capacity.

\subsection{Not-so-successful countries}

Many countries in South-East Asia, South Asia, Latin America, and Central and East Europe have managed to leverage SEZs to bring about economic transformation. However, such transformation is essentially driven by successful SEZ localities; the success of these localities in strengthening the productive capacity in the wider economy has remained limited. The prominent countries that qualify in this group are Cambodia, Indonesia, Malaysia, the Philippines, Thailand and Viet Nam in South-East Asia; Bangladesh, India and Sri Lanka in South Asia; Costa Rica, El Salvador, Guatemala, Honduras and Nicaragua in Central America; the Dominican Republic, Jamaica and Panama in the Caribbean Basin; Mexico in North America; Poland in Central and East Europe; Egypt, Jordan, Morocco, Tunisia and the United Arab Emirates in the Middle East and North Africa; and Mauritius in subSaharan Africa. SEZs became instrumental in the emergence and growth of electronics processing (as in Costa Rica, Indonesia, Malaysia and the Philippines), the automobile industry (Mexico, Morocco, Poland, Thailand and Tunisia); the information technology industry (Ghana, India and the Philippines); and textile, apparel and other light industries (Bangladesh, Mauritius, Sri Lanka, Viet Nam, as well as countries in the Middle East and North Africa and Central American and Caribbean countries). SEZs account for a sizeable share of exports, FDI and in some cases even employment in these countries. For instance, in 2010 the electronics sector in Malaysia contributed 27 per cent of the country's manufacturing output, 49 per cent of exports and 32.5 per cent of overall employment (Rasiah et al., 2015). Economic zones in the Philippines in 2011 accounted for 73 per cent of exports and 2 per cent of employment. ${ }^{3}$ In Bangladesh, eight small traditional

3 https://business.inquirer.net/203800/special-economic-zones-boon-asia-says-adb. 
EPZs employed 283,620 workers and accounted for 20 per cent of total exports in 2016-17. In Thailand, automotive exports in 2014 made up 16 per cent of total merchandise exports and 19 per cent of total manufactured goods exports (Warr, 2017). In the Dominican Republic, SEZ exports accounted for 58 per cent of total exports in 2014-15. This share was 80 per cent in the early 2000s (World Bank, 2016). Over 2,800 Maquiladora companies operating in Mexico account for over 55 per cent of Mexico's exports and 15 per cent of manufacturing employment ${ }^{4}$. Free zone trade accounts for a third of the United Arab Emirates's non-oil economy and approximately 80 per cent of non-oil exports (OECD, 2018). The Tanger Med Zones in Morocco accounted for approximately 25 per cent of national exports in 2016 (COMCEC, 2017).

Although SEZs have contributed to the production and export structures in these economies by successfully integrating them into GVCs, their role in building productive capacities in the rest of the economy has remained marginal (see, for instance, Hausman et al., 2017; Frick et al., 2018; Heron, 2006 for Latin America; OECD, 2017 and KPMG, 2014 for Central and East Europe; Dassel et al., 2013 for the Middle East and North Africa; Manasan, 2013 for the Philippines; Rasiah et al., 2015 for Malaysia; Karunaratne and Abayasekara, 2012 for Sri Lanka). The zones fuelled economic growth in Caribbean and Central American countries during the 1990s and the early 2000s. In the 1990s primary goods accounted for more than half of total exports in goods, and by 2006 their share had fallen to one-third. But the expiry of the Multi-Fibre Agreement led to unprecedented rates of bankruptcy, capital flight and job loss in the face of strong competition in the textile and apparel industry from Asia (World Bank, 2016). Mauritius, which is normally viewed as a successful case, underwent a similar experience. South-East Asia, which has seen phenomenal growth in exports and built impressive production capabilities in SEZs in relatively high-skill sectors, could not manage to leap to high-income status. Most production at the high end is dominated by foreign multinationals, while lowend activities are performed by local companies. There is thus a question mark on the viability of this model of SEZs. What went wrong?

Lack of integration between development planning and SEZs: Most of these countries have set up SEZs as "industrial infrastructure" especially as a way of attracting FDI, mostly in the manufacturing sector; creating jobs; and generating exports and foreign exchange without aligning them with broader development planning. Most of these countries were early adopters of SEZs and are endowed with natural advantages in exporting, largely related to their geography and factor endowment. They managed to effectively leverage their SEZs to strengthen 4 http://teamnafta.com/manufacturing-resources-pages/2016/4/18/nafta-and-the-maquiladora-
program. 
their natural advantages and built impressive production capabilities in SEZs by keeping business costs low. In Malaysia, which is one of the most developed of the developing countries, a staggering 93.23 per cent (close to US\$6 billion) of the electronics sector investment in 2011 was foreign, originating mainly from Japan, the United States and Germany (Rasiah et al., 2015). Upgrading and spillovers are limited to Penang, which is due to a well-documented proactive approach of the regional government that integrated its SEZ development with the regional development plan. Bangladesh succeeded in becoming the second largest exporter of apparel but even after more than 50 years of SEZ experience, it still focuses on the volume-based segment of the industry. Not only that, it continues to import spinning, knitting, weaving, dyeing and other machinery worth billions of foreign exchange. The story is not very different in other countries. Apparently, in the absence of any strategic planning, there are no automatic spillovers and SEZs remain enclaves of $\mathrm{FDI}$ and trade.

Lack of dynamism in SEZ approach: Encouraged by the performance of SEZs, these countries are continuously expanding the number of SEZs with little dynamism in the approach. The underlying objective is to create these zones in newer areas, newer sectors and with more innovative features, to attract FDI. Thus the number of zones continues to increase unrelated to the development process outside the economy. The government of Bangladesh, for instance, has set a target to build 100 economic zones under public-private arrangement by 2030. Sri Lanka has announced four new zones with a budgetary allocation of Rs. 2.5 billion. ${ }^{5}$ Viet Nam has set up more than 300 zones and is now planning to set up large comprehensive SEZs with attractive incentives. So are other countries in the region: Indonesia, the Lao People's Democratic Republic, Malaysia, the Philippines and Thailand. In the absence of dynamism in the zones, mature economies are now competing with emerging low-cost destinations to maintain their competitive advantages in low-end activities. Evidence suggests that in Malaysia EPZ firms have successfully lobbied to keep the market open for migrant workers (Rasiah et al., 2015; Henderson and Phillips, 2007; SOMO, 2013), to keep it artificially attractive to low-value operations. Similar patterns are observed in Latin America. The number of industrial parks in the Dominican Republic, which stood at 60 in 2014 has grown to 74 over the past 5 years ${ }^{6}$. Furthermore, most Latin American countries have plans to expand their SEZs over the next few years (Mitchell, 2017). Many of these countries are resorting to competitive currency devaluations to continue to attract multinational corporations. There is thus an intensification of regional competition to attract FDI in the zones. In Central and East Europe, Poland initially established SEZs for periods of 20 years. Since then it has extended the programme continuously to keep its

5 http://www.ft.Ik/front-page/Govt--steams-ahead-to-boost-exports--FDIs/44-670322.

6 https://www.state.gov/reports/2019-investment-climate-statements/dominican-republic/ 
SEZs alive. Recently, a new law has extended the SEZ benefits to all of Poland's surface area. Other major economies in the region have adopted similar measures to attract FDI. But the development impacts on the wider economy have been marginal.

Implementation: Effective implementation is the key factor that explains why these countries succeeded with SEZs. Many would attribute it to the best practices followed by these countries in designing, developing and operating their SEZs. Indeed, the SEZs have met foreign investors' expectations and proven to be ideal destinations for keeping costs low. However, a host of other factors that are often overlooked also explain the effective implementation of SEZs in these countries: for instance, political support, political stability, successful management of macro policies, pro-trade exchange rates and trade policies, participation in regional trading agreements, successful promotion of SEZs and so on and so forth. Further, with few exceptions, most of these economies were early movers and faced little competition. Very importantly, however, they have been able to leverage their geographical and factor endowments to promote SEZs. These countries compare fairly well with most other developing countries in terms of their locations on international trade routes to serve a sizeable regional and international market; direct access to the sea; their proximity to core developed markets in each region; preferential access offered by the large countries; and an abundance of both labour supply and human skills. In Central America, the Caribbean countries and Mexico benefitted from their proximity to the United States and various programmes and agreements on duty-free access to the United States market for most goods; the Middle East and North Africa benefitted from its proximity to European markets; and North and South-East Asia reap the benefits of Japanese investment. And as noted above, abundant supplies of labour and human skills complemented their geographic endowments.

Most of these countries embraced SEZs and leveraged them to exploit natural advantages to drive economic development in the initial phases. However, in the absence of a strategic approach to integrate SEZs into overall development planning and upgrading, they continued to remain enclaves of FDI, generating foreign exchange and employment. Such countries are essentially weak developmental states that have failed to make the hard decisions necessary to upgrade the wider economy. Lack of political will affects bureaucratic motivation as well. They are thus trapped in the low end of GVCs and continue to compete with lesser developed countries in this segment.

\subsection{Least successful countries}

Countries in sub-Saharan Africa and Central Asia are relative latecomers to economic zones. Kenya, Liberia and Mauritius took the lead to set up SEZs in 
the 1970s. However, Mauritius alone succeeded; SEZs in the other two countries were dormant. In the post-1990 period, Africa witnessed a mushrooming of SEZs. Currently 43 of 54 African countries have passed SEZ legislation. Central Asian economies embraced the policy in the post-2000 period. Currently, all five of them have an SEZ regime in place. Empirical evidence suggests that SEZs in these regions have, by and large, been unsuccessful even in attracting investment. Although most literature focuses on Africa, the evidence from Central Asia is no different (ADB, 2018).

What explains these failures? One argument could be that investment is impeded by structural factors in these economies. Most of these economies are endowed with natural resources which together with heavy foreign aid flows have created a "resource curse"-like situation. These countries thus lose competitiveness in tradable sectors, other than the primary sector, due to relatively high foreign exchange rates and high wages. Further, many countries in these regions are landlocked, a condition that adds to the costs of logistics and trade. SEZs are typically seen as compensating for an overall lack of competitiveness by offering extended tax holidays, subsidised real estate, utilities and direct financial incentives to individual investors to attract investment. However, the available evidence indicates that the incentive package cannot compensate for lack of competitiveness. Investor flight from SEZs in Latin American and African countries on the expiry of the Multi-Fibre Arrangement is a case in point.

Although the structural impediments cannot be underestimated, they can be overcome. Egypt, Jordan, Morocco, Tunisia and the United Arab Emirates have all managed to generate substantial gains from their SEZs. Even sub-Saharan countries - Ethiopia, Ghana and Kenya - have shown dynamism in their SEZs. The SEZ failures may thus additionally be explained by bureaucratic failures to appropriately address the multiple challenges of SEZ establishment. A number of factors to which the underperformance of SEZs has been attributed pertain to the poor investment climate within and outside SEZs, including weak industrial, transport and communication infrastructure; poor planning and management; excessive regulation; rent seeking; unsuitable locations; low-productivity labour supplies; and a lack of an industrial culture (ADB, 2018; Zeng, 2012; Farole, 2011). These are clear manifestations of bureaucratic failures and the lack of technical, sociopolitical and economic management skills and motivations. At the root of this lies the predatory nature of these states. Many of these countries are resourcerich and have autocratic governments that exercise unconstrained political authority through "extensive networks of personal patronage that include inefficient bureaucracies staffed with officials selected for their political loyalties rather than for their technical qualifications" (Reno, 2015:731). The fact that many of these countries are high on the fragility index due to ethnic violence, political instability and rampant corruption bears testament to the predatory nature of the state. SEZs 
in these countries may thus be a tool to enhance the political power and wealth through patronage, rather than to bring about economic transformation.

\section{Conclusion}

SEZs have long been characterised by ideological debates and political sensitivities. Their economic benefits relative to their costs are under deep scrutiny. Their development role is not appreciated owing to the limited evidence of SEZ-induced development.

This study revisits the SEZ experience of successful, not-so-successful and least successful countries across the globe within the three-pillared "integrated institutional framework" that is proposed here and reveals that SEZ-induced economic development is positively related with the developmental role of the state. A strong developmental state with leadership that can energise and motivate bureaucracies to achieve the broader development goals is a prerequisite for SEZled economic transformation. Weak developmental states can drive investment and trade and generate employment by effectively implementing their SEZs. However, in the absence of any strategic intervention, they continue to sustain their cost advantages at the low end of activities. A serious risk with this strategy in these countries, is that it can delay industrialisation in an economy by diverting resources and the attention of policymakers away from upgrading domestic capabilities and toward expanding SEZs. Under predatory systems of governance, SEZs may simply be used as a rent-seeking tool to extend political influences and loyalties or even laundering money rather than promoting productive capacities. There is thus a need to have a fresh look at the viability of SEZs as engines of economic transformation. 


\section{References}

ADB (2018a). Strategic framework for special economic zones and industrial zones in Kazakhstan. Asian Development Bank, Manila.

ADB (2018b). Strategic framework for free economic zones and industrial parks in the Kyrgyz Republic. Asian Development Bank, Manila.

Aggarwal, A. (2012a). Social and economic impact of SEZs in India. OUP Catalogue. New Delhi: Oxford University Press.

Aggarwal, A. (2012b). SEZ-led growth in Taiwan, Korea, and India: Implementing a successful strategy. Asian Survey 52 (5): 872-99.

Amsden, A. (1989). Asia's Next Giant: South Korea and Late Industrialization. New York: Oxford University Press.

Baldwin, R. (2013). Global supply chains: Why they emerged, why they matter, and where they are going, in Deborah, K.E. and Patrick, L. (eds.), Global Value Chains in a Changing World. Switzerland: Fung Global Institute, Nanyang Technological University, and World Trade Organization Secretariat.

Bertaud, A. (2016). The new Chinese city clusters: Would the current urban transport technology be able to serve these very large urban labor markets? World Resources Institute. December 14, http://www.wri.org/sites/default/files/new-chinese-city-clusters. pdf.

COMCEC (2017) Special Economic Zones in the OIC Region: Learning from Experience , Report submitted to the COMCEC Coordination Office.

Crook, S. (2016). Taiwan's export processing zones: Forward-looking at 50, Taiwan Business Topics, December 19, 2016.

Dassel, K., Eckermann, K., and Barclay, S. (2013). Economic security and competitiveness: using special economic zones to drive job creation in MENA. Monitor Deloitte, https:// www2.deloitte.com/content/dam/Deloitte/us/Documents/strategy/us-consultingeconomicsecurity.pdf.

Ellison, B.A. (1995). A conceptual framework for analyzing bureaucratic politics and autonomy. The American Review of Public Administration, 25 (2), 161-182.

Evans, P. (1995). Embedded Autonomy: States and Industrial Transformation. Princeton: Princeton University Press.

Farole, T. (2011). Special Economic Zones in Africa: Comparing Performance and Learning from Global Experiences. Washington, DC: World Bank Publications.

FIAS (2008). Special economic zones: Performance, lessons learned and implications for zone development. Report of Facility for Investment Climate Advisory Services, the multidonor service managed by the International Finance Corporation. Unpublished. World Bank Publications, Washington, DC.

Frick, S.A., Rodríguez-Pose, A. and Wong, M. D. (2018). Towards economically dynamic Special Economic Zones in emerging countries. Journal of Economic Geography, 95(1), 30-64. 
Gibbon, P., Bair, J., and Ponte, S. (2008). Governing global value chains: An introduction. Economy and Society, 37 (3), 315-38.

GOC (2015). China Statistical Yearbook, 2015, http://www.stats.gov.cn/tjsj/ndsj/2015/ indexeh.htm.

Hausmann, R., Obach, J., and Santos, M.A. (2017). Special economic zones in Panama: Technology spillovers from a labor market perspective. Working paper, Harvard University Center for International Development, Cambridge, MA.

Henderson, J., and Phillips, R. (2007). Unintended consequences: social policy, state institutions and the "stalling" of the Malaysian industrialization project. Economy and Society, 36(1), 78-102.

Heron, T. (2004). The New Political Economy of United States-Caribbean Relations: The Apparel Industry and the Politics of NAFTA Parity. Milton Park, U.K.: Routledge.

Jenkins, M., Esquivel, G. and Larraine, B. (1998). Export processing zones in Central America. Development Discussion Papers, Central America Project Series, Discussion paper no. 4. Harvard Institute for International Development, Harvard University, Cambridge, U.K.

Karunaratne, C., and Abayasekara, A. (2013). Impact of EPZs on poverty reduction and trade facilitation in Sri Lanka. ARTNeT Working Paper Series No. 134, Bangkok, ESCAP.

KPMG (2014). 20 years of special economic zones in Poland: A guide to SEZs. https://www. paih.gov.pl/files/?id_plik=24349.

Manasan, R.G. 2013. Export processing zones, special economic zones: Do we really need to have more of them? Policy Notes, Philippine Institute for Development Studies, Makati City.

Matland, R.E. 1995. Synthesizing the implementation literature: The ambiguity-conflict model of policy implementation. Journal of Public Administration Research and Theory, 5(2), 145-174.

Milberg, W. 2007. "Export Processing Zones, Industrial Upgrading and Economic Development: A Survey." Working Paper Series, Schwartz Center for Economic Policy Analysis and Department of Economics, The New School for Social Research, New York.

Milberg, W., Jiang, X., and Gereffi, G. (2014). Industrial policy in the era of vertically specialized industrialization, in Salazar-Xirinachs, J., and Kozul-Wright, R. (eds.), Transforming Economies: Making Industrial Policy Work for Growth, Jobs and Development. Geneva: UNCTAD and ILO.

Mitchell J. (2017). Latin America braced for SEZ surge, FDI magazine, 16 Feb. 2017: Financial Times publication.

OECD (2017). Tracking special economic zones in the western Balkans: Objectives, features and key challenges. Organisation for Economic Co-operation and Development, Paris.

OECD (2018) Trends in trade and investment policies in the MENA region: background note http://www.oecd.org/mena/competitiveness/WGTI2018-Trends-Trade-InvestmentPolicies-MENA-Nasser-Saidi.pdf last accessed on 10 August, 2019.

Rasiah, R., Crinis, V., and Lee, Hwok-Aun (2015). Industrialization and labour in Malaysia. Journal of the Asia Pacific Economy, 20 (1): 77-99. 
Reno, W. (2015). Predatory states and state transformation, in Leibfried, S., Huber, E., Lange, M., Levy, J.D., and Stephens, J.D. (eds.), The Oxford Handbook of Transformations of the State. Oxford, U.K.: Oxford University Press.

SaKong, I., and Koh, Y. (eds.) (2010). The Korean Economy: Six Decades of Growth and Development. Seoul: Korea Development Institute.

SOMO (2013). Outsourcing labour: Migrant labour rights in Malaysia's electronics industry. Somo Centre for Research on Multinational Corporations, Amsterdam.

UNCTAD, 2019. World Investment Report 2019: Special Economic Zones. New York and Geneva: United Nations.

Wade, R. (1990). Governing the Market: Economic Theory and the Role of Government in Taiwan's Industrialization. Princeton, NJ: Princeton University Press.

Wang, J. (2013). "The economic impact of Special Economic Zones: Evidence from Chinese municipalities," Journal of Development Economics, 101(C):133-147.

Wang, K.S. (1990). Linkage effects in Taiwan EPZs, in Bolin, R.L. (ed.), Linking the Export Processing Zone to Local Industry. Flagstaff, AZ: Flagstaff Institute.

Warr, P., and Kohpaiboon, A. (2017). Thailand's automotive manufacturing corridor. ADB Economics Working Paper Series 519. Asian Development Bank, Manila.

World Bank (2016). Special Economic Zones in the Dominican Republic: Policy Considerations for a More Competitive and Inclusive Sector. World Bank, Washington DC.

WTO. (2012). Trade Policy Review, South Korea. Geneva: WTO.

Zheng, D.Z (2016). Global experiences of special economic zones with focus on China and Africa: Policy insights. Journal of International Commerce, Economics and Policy, 7(3). 